\title{
Sikap Kepemimpinan Wirausahawan Millenial dalam Perspektif Chief Executive Officer (CEO) Millenial
}

\author{
Monalisa, Muhammad Akhyar, Musa Pelu \\ Universitas Sebelas Maret \\ monalisapurba98@gmail.com
}

\section{Article History}

received 1/9/2021

revised $1 / 10 / 2021$

accepted 1/11/2021

\begin{abstract}
Being a millennial entrepreneur who serves as a professional CEO, despite his young age as a millennial generation, there are several main approaches to leadership that need to be done by a millennial CEO that is seen from the point of view of millennial netizens. So how millennial entrepreneurs have a leadership attitude to become a millennial CEO who can increase professional value among relationships, customers and the wider community. The method used in this study is case studies with qualitative approaches. The type of data used is primary data through instagram social media surveys to see the activities of millennial entrepreneurs who reflect the leadership attitude of a millennial CEO. The sample of concern is CEO Indra Kesuma, a millennial entrepreneur from the field with his business instagram account kursustrading.id, action.kindness and others. And Esther Nathalia who became the CEO of millennials of my produktifkuy Instagram account. The results of the research findings are that millennial entrepreneurs with ceo positions in their businesses, have an advanced leadership attitude. Millennial CEOs are hardworking, resilient, responsible, and still care about the people below by helping and helping them both help in the form of money, open jobs and provide very useful knowledge through instagram content shared. In conclusion, although millennials are considered a vulnerable generation of despair, they show their own value through their leadership attitude in developing their entrepreneurship.
\end{abstract}

Keywords: Attitude, Leadership, entrepreneur, millennial, CEO, Chief Executive Officier

\begin{abstract}
Abstrak
Menjadi wirausahaan millenial yang menjabat sebagai CEO profesional, meskipun usianya terbilang muda sebagai generasi millenial, ada beberapa pendekatan utama kepemimpinan yang perlu dilakukan oleh seorang CEO millenial yang dilihat dari sudut pandang netizen millenial. Sehingga Bagaimana wirausahawan millenial mempunyai sikap kepemimpinan agar menjadi CEO yang millenial yang dapat meningkatkan nilai profesional di kalangan relasi, pelanggan dan masyarakat luas. Metode yang digunakan dalam penelitian ini adalah Studi kasus dengan pendekatan kualitatif. Jenis data yang digunakan adalah data primer melalui survei media sosial instagram untuk melihat aktifitas kehidupan wirausahaan millenial yang mencerminkan sikap kepemimpinan seorang CEO millenial. Sampel yang menjadi perhatian adalah CEO Indra Kesuma, seorang wirausahaan millenial berasal dari medan dengan akun instagram usahanya kursustrading.id, aksi.kebaikan dan lainnya. Serta Esther Nathalia seorang yang menjadi CEO millenial akun instagram produktifkuy. Hasil temuan penelitian yaitu wirausahaan millenial dengan jabatan CEO di usahanya, memiliki sikap kepemimpinan yang maju. CEO millenial pekerja keras, tangguh, bertanggung jawab, dan masih peduli kepada rakyat bawah dengan menolong dan membantunya baik membantu berupa uang, membuka lapangan pekerjaan serta memberikan ilmu-ilmu yang sangat bermanfaat melalui konten instagram yang di share. Kesimpulannya, meskipun kaum millenial dianggap generasi yang rentan putus asa, mereka menunjukkan nilainya tersendiri melalui sikap kepemimpinannya dalam mengembangkan wirausahanya.
\end{abstract}

Kata kunci: Sikap, Kepemimpinan, wirausahawan, millenial, CEO, Chief Executive Officier

Social, Humanities, and Education Studies (SHEs): Conference Series p-ISSN 2620-9284 https://jurnal.uns.ac.id/shes e-ISSN 2620-9292 


\section{PENDAHULUAN}

Sikap kepemimpinan seorang wirausahaan millenial sangat penting untuk kesuksesan usaha yang didirikannya. Millenial atau generasi muda sangat rentan putus asa dalam membangun usaha ketika mengalami kekurangan pendapatan. Secara emosional, generasi millenial ketika ada masalah yang menimpanya, mereka secara cepat mengambil keputusan dengan tergesa-gesa tanpa memikirkan risiko yang terjadi.

Hal inilah yang menyebabkan kekacauan dalam usahanya, apabila seorang pemimpin wirausaha tidak mempunyai sikap kepemimpinan yang positif. Kaum millenial yang ingin mendirikan usaha dan ingin mengembangkan usahanya harus mempunyai sikap kepemimpinan. Namun, disisi lain seorang millenial yang mempunyai sikap kepemimpinan tidak memiliki keinginannya untuk membangun usahanya sendiri. Hal ini menunjukkan bahwa seseorang yang mempunyai sikap terhadap perilaku yang tinggi belum tentu orang tersebut mempunyai keinginan untuk berwirausaha.

Secara umum orang membenarkan bahwa keberhasilan usaha dapat tercapai jika memiliki karakteristik wirausahawan seperti rasa percaya diri, berorientasi pada tugas dan hasil, berani mengambil risiko, memiliki jiwa kepemimpinan yang baik, memiliki keorisinalan, dan berorientasi pada masa depan. Ditambah dengan sikap seorang wirausahawan yang berhasil kalau ia disiplin, memiliki komitmen yang tinggi, jujur, kreatif dan inovatif, mandiri, dan realistis. Demikian pula pastinya seorang wirausahawan akan berhasil, kalau ia memiliki keterampilan teknis, keterampilan manajemen bisnis, dan keterampilan berkewirausahaan secara personal. (Andreas Sarjono, Maria Josephine, 2019)

Selain itu, Spiritualitas dan kepuasan hidup mempunyai peran yang signifikan bagi kualitas hidup wirausahawan khususnya wirausahawan muda. Ini menunjukkan bahwa aktivitas usaha tidak hanya soal pertumbuhan ekonomi dan keuntungan semata tetapi juga pertumbuhan internal wirausahawan itu sendiri. Tujuan penulisan ini untuk mengetahui apakah wirausahaan millenial mempunyai sikap kepemimpinan wirausahaan yang positif dalam Perspektif CEO atau hanya mengikuti trend CEO atau tren mendirikan sebuah usaha saja tanpa memiliki sikap yang membangun usahanya serta mengetahui apakah generasi millenial mempunyai sikap yang positif untuk dirinya, teman sejawatnya dan juga masyarakat yang lain. Sehingga penulis mengambil judul sikap kepemimpinan wirausahawan millenial dalam perspektif Chief Executive Officer (CEO) Millenial.

\section{KAJIAN TEORI}

\section{A. Kepemimpinan}

Kepemimpinan merupakan proses mempengaruhi orang lain untuk bekerja secara sukarela terhadap suatu tujuan organisasi (Igbaekemen, 2014). Kepemimpinan juga merupakan keterampilan yang dimiliki oleh seorang pemimpin untuk menginspirasi dan memotivasi anggota organisasi untuk mencapai tujuan organisasi (Ainur, 2017).

Jadi teori kepemimpinan pada dasarnya merupakan kajian tentang individu yang memiliki karakteristik fisik, mental, dan kedudukan yang dipandang lebih daripada individu lain dalam suatu kelompok. Sehingga individu yang bersangkutan dapat mempengaruhi individu lain dalam kelompok tersebut untuk bertindak ke arah pencapaian suatu tujuan (Udik Budi Wibowo, 2011).

Salah satu konsep kepemimpinan Jawa merupakan ajaran Asta (Astha) Brata. Astha Brata secara etimologis berasal dari bahasa Sansekerta, yang mana Asta berarti delapan; dan Brata berarti laku atau pedoman. Ajaran asta brata tersebut pada intinya memuat delapan ajaran perilaku kepemimpinan yang disimbolisasikan dengan sifat- 
sifat dewa alam, yaitu: langit, matahari, angin, air, samudra, bulan, bintang, dan api (Sariyatun, 2017).

Pertama matahari, pemimpin memiliki sifat berhati-hati dalam membimbing bawahannya. Pemimpin mampu memberikan dorongan energi kepada para bawahan atau rekan kerjanya secara perlahan, yang tanpa disadari akan membimbingnya dalam menjalankan tujuan bersama. Kedua angin, pemimpin memiliki sifat teliti ketika turun langsung memperhatikan atau mengawasi kinerja semua karyawan atau rekan kerjanya. Pemimpin harus berada dekat dengan karyawan atau rekan kerjanya tanpa membedakan statusnya.

Ketiga bulan, pemimpin memiliki sifat periang yang mampu menyenangkan hati semua karyawan atau rekan kerja. Pemimpin mampu memberikan motivasi kepada mereka agar performa kinerjanya meningkat. Keempat api, pemimpin memiliki sifat tegas dalam memerintah, terutama saat memberikan hukuman pada karyawan yang melakukan kesalahan. Pemimpin harus berani mengambil keputusan untuk menghukum bahkan mengeluarkan karyawannya yang bersalah dalam kelompok.

Kelima bumi, pemimpin memiliki sifat murah hati dan adil terhadap semua pengikutnya. Pemimpin bersikap adil dengan memberikan penghargaan bagi para karyawan atau rekan kerjanya yang berprestasi tanpa membedakan statusnya. Keenam langit, pemimpin memiliki sifat mampu memberi nilai tambah keilmuan kepada para karyawannya. Pemimpin harus memiliki bekal keluasan pengetahuan atau kompetensi yang dapat diajarkan kepada para karyawan dan rekan kerjanya.

Ketujuh samudra, pemimpin memiliki sikap terbuka dan mampu menampung aspirasi dari semua karyawannya. Pemimpin hendaknya bersikap bijak dalam menyikapi setiap kritik dari karyawan dan rekan kerja. Kedelapan bintang, pemimpin memiliki sifat percaya diri dalam memegang teguh prinsip yang diyakininya. Prinsip kuat yang dimiliki pemimpin merupakan pedoman karyawan dalam bekerjasama mencapai tujuan. (Anggoro \& Virdanianty, 2011)

\section{B. Wirausahawan}

Wirausahawan yang sukses mempunyai daya inisiatif yang tinggi karena dengan inisiatif wirausahawan tersebut mempunyai kecendrungan untuk melihat dan menganalisis sesuatu situasi ataukeadaan dengan cakap. Hasil daripada sikap tanpa menunggu diarahkan atau dipaksa untuk melakukan sesuatu maka individu itu dapat melihat aspek-aspek yang perlu dilakukan melalui intuisi dan imajinasinya. Dengan demikian sikap ini akan membawa diri wirausahawan berkenaan selangkah lebih maju daripada orang lain (Radzali, 1991).

Kehadiran wirausaha menjadi penting untuk melatih mengembangkan sikap mental agar berhasil meraih keuntungan yang besar. Sehingga perlu dibiasakan dapat memiliki daya fikir kreatif, yang meliputi berfikir maju, Berusaha menarik pelajaran dari setiap kegagalan, Mengutamakan efisiensi, Bersedia menampung saran orang lain, Kewaspadaan mental. Sikap mental wirausaha merupakan suatu sikap untuk memberantas rasa rendah diri, malas dan berbagai sikap negatif lainnya. Pada dasarnya di samping memiliki sifat negatif, hal tersebut merupakan kodrat manusia dari yang lebih penting adalah bagaimana membangkitkan dan menumbuhkan ciri-ciri positif yang dimiliki manusia sekaligus dapat mengurangi dan menghilangkan ciri-ciri negatifnya (Dyah Suryaningtyas, 2004).

Berpandangan jauh ke depan, ingatlah Lifes Cycle of Corporation, dengan adanya dinamika kehidupan perusahaan yang senantiasa fluctuative. Ada masa wirausahawan menanjak, ada masa puncak, ada masa menurun serta kemungkinan ada masa kebangkrutan. Oleh karena itu, pada saat mengalami "boom" atas bisnis yang dijalankan, hendaknya mencari bisnis lain yang sedang ngetrend di masyarakat (Ali Chaerudin, 2012). 


\section{Generasi Millenial}

Generasi Millenial merupakan generasi yang lahir pada era internet yang pada booming atau era serba digital. Ciri - Ciri dari generasi Millenial yaitu karakteristik, masing- masing berbeda tergantung dimana ia di besarkan, strata perekonomi, sosial dan keluarganya, pola komunikasinya sangat terbuka dibanding generasi sebelumnya, pemakai media sosial yang fanatic serta kehidupannya sangat terpengaruh dengan perkembangan teknologi (Sri Laila Afrika Dewi, Ratu Mutialela Caropeboka, 2020).

Dengan alat canggih yang mereka punya, generasi millenial dapat mencari informasi dan menyerap dengan cepat. Tidak hanya informasi yang didapat, generasi millenial merasa seakan-akan paling benar dengan pendapat mereka. Secara tidak sadar, mereka menjadi malas dengan mencari kebenaran atas suatu informasi. Informasi yang menjadi berita terbaru atau viral dengan mudah mereka percayai.

Sedangkan potensi generasi milenial yang dapat dimaksimalkan akan mampu meningkatkan pertumbuhan ekonomi. Selain itu, peran generasi milenial yang merata tanpa adanya kesenjangan gender juga akan mengoptimalkan manfaat dan potensi yang ada (Kementerian Pemberdayaan Perempuan dan Perlindungan Anak \& Badan Pusat Statistik, 2018).

\section{Chief Executive Officer (CEO)}

Chief executive officer (CEO) atau di Indonesia lebih dikenal dengan sebutan direktur utama atau presiden direktur, merupakan posisi tertinggi dalam jajaran eksekutif yang bertanggung jawab atas seluruh kegiatan operasional perusahaan. Investor dapat menilai perusahaan dengan mengetahui CEO perusahaan tersebut. Certo, Holmes, dan Holcomb (2007) menyatakan bahwa CEO mempunyai kekuasaan (power)untuk memengaruhi keputusan investasi dari investor potensial. Power atau kekuasaan yang dimiliki CEO dapat berasal dari kepemilikan saham (ownership power), jabatan formal (structural power), keahlian (expert power), dan koneksi sosial (prestige power), yang merupakan informasi non-finansial yang juga digunakan sebagai pertimbangan investor untuk menilai prospek perusahaan di masa yang akan datang. Investor akan bersedia membeli saham perusahaan dengan harga tinggi bila investor yakin terhadap kepemimpinan $\mathrm{CEO}$, sehingga perusahaan mendapatkan premium dari penjualan saham perdana yang dapat menguntungkan perusahaan. (Made Sudana dan Ni Putu Nina Aristina, 2017)

Ketika CEO terlalu optimis, mereka cenderung futuristik dan memancarkan keyakinan bahwa tujuan yang ditetapkan akan dapat dicapai. Oleh karena itu, dengan cara ini anggota yang terbuka cenderung menciptakan ruang untuk ide-ide dan sebagai hasilnya dapat menyarankan berdasarkan pengetahuan pribadi mereka. Dengan demikian disimpulkan bahwa optimisme CEO adalah kunci untuk keputusan anggota yang strategis seperti inovasi perusahaan. (Joel Tuwey, Vincent Ngeno, 2019)

\section{METODE}

Metode yang digunakan dalam penelitian ini adalah Studi kasus dengan pendekatan kualitatif. Jenis data yang digunakan adalah data primer melalui survei media sosial instagram untuk melihat aktifitas kehidupan wirausahaan millenial yang mencerminkan sikap kepemimpinan seorang CEO millenial. Sampel yang menjadi perhatian adalah CEO Indra Kesuma, seorang wirausahaan millenial berasal dari medan dengan akun instagram usahanya kursustrading.id, aksi.kebaikan dan lainnya. Serta Esther Nathalia seorang yang menjadi CEO millenial akun instagram produktifkuy..

\section{HASIL DAN PEMBAHASAN}

Ada dua generasi millenial yang menjadi seorang wirausahaan yang memiliki sikap kepemimpinan yang positif, yaitu Indra Kesuma dan Esther Nathalia. Pertama, 
Indra Kesuma atau pemilik akun instagram Indra Kenz merupakan seorang generasi muda yang mempunyai usaha terbilang sukses. la lulusan Teknik Sipil yang berasal dari Medan, Indonesia. la mendirikan perusahaan kursustrading.id, botxofficial, disotiv, redwolfindonesia, miejongkok, litterallycafe, dan aksi kebaikan. Bukan hanya menjalani sebuah wirausaha dengan profit sebagai tujuan utamanya. Namun, wirausaha yang berdampak positif bagi masyarakat sekitar. Sebelum Indra Kenz membuka usaha serta seterkenal sekarang, ia merupakan seorang yang pekerja keras mulai dari menjadi karyawan asuransi, penyanyi jalan dan sebagainya. Semangat juangnya tak pernah pudar bagi generasi millenial.

Dalam mengalami penurunan pendapatan akibat pandemi covid-19, Indra Kensuma membangun bisnis lain dan membuka lapangan pekerjaan untuk kalangan muda yang masih mencari pekerjaan. Serta tetap membagikan kebaikan kepada anakanak penerus bangsa dengan memberikan pembelajaran atau kursus gratis kepada anak jalanan atau anak kurang mampu secara materi. la juga turun langsung ke lapangan untuk melihat kondisi pembelajaran dan memberikan motivasi kepada anakanak jalanan. Selain, membagi rejeki kepada anak-anak melalui program aksi kebaikan miliknya, la juga membagikan rejeki kepada pengikut instagramnya tanpa menyadari bahwa telah memberikan banyak untuk orang lain.

Ketika masyarakat atau rekan kerjanya mengalami masalah seperti tertipu oleh oknum yang tidak bertanggung jawab, Indra Kesuma menegaskan dan mengambil keputusan untuk langsung menshare bahwa itu penipuan. Bahkan ketika ada yang viral seperti robot trading, ia segera mengambil tindakan untuk mencobanya terlebih dahulu lalu mereviewnya dengan memberikan penjelasan hati-hati melalui akun instagram dan youtobenya. Indra Kenz juga berlapang dada untuk menerima pendapat sekitar seperti pendapat rekan kerjanya. Sehingga ia mendapatkan pengetahuan baru dari rekan kerjanya untuk mendapatkan profit dalam tradingnya.

Sama seperti simbol kepemimpinan jawa astha brata yaitu langit, Indra Kenz mempunyai kompetensi, kemampuan, dan kecakapan yang dapat diajarkan pada orang lain khususnya kepada membernya di program kursustrading.id. Program kursustrading.id tersebut merupakan program yang bisa diikuti oleh siapapun sedangkan kursus trading private merupakan usahanya yang ia sendiri dan bersama rekannya memberikan arahan kepada membernya. Karena sebelum membangun usaha atau perusahaannya, ia terus belajar dan berlatih tentang grafik trading tersebut.

Selain banyaknya kegiatan karena menjadi wirausahawan millenial, ia bersama rekan kerjanya yang merupakan generasi millenial juga produktif dalam mengurus perusahaan dan tetap melakukan self development. Di dalam keluargapun, Indra Kenz tetap menghargai dan menghormati kedua orangtuanya. Serta ia berhasil membangun rumah untuk keluarganya.

Sedangkan Esther Nathalia Lubis adalah seorang mahasiswi fakultas hukum Universitas Gajah Mada dan seorang pembicara atau moderator dalam rangkaian webinar. Esther selain mahasiswi, ia berkerja di Indosatooredoo, akademis.id, dan alsalcugm serta ia mendirikan perusahaan produktifkuy. Melalui akun instagramnya, personal brandingnya sangat bagus. Dari sudut pandang penulis yaitu generasi millenial, Esther merupakan salah satu generasi millenial yang mempunyai sikap kepemimpinan yang positif untuk dirinya, keluarga, teman, dan orang lain. Dalam aktivitasnya sehari-hari ia membagikannya lewat instastory instagramnya yang bernama esthernataliaa. Instastory tersebut meliputi kegiatan kuliahnya dan pekerjaannya. Meskipun ia seorang mahasiswi, Esther tetap memprioritaskan kuliahnya terlebih dahulu.

Esther Nathalia mempunyai sikap kepemimpinan positif yaitu mendirikan program produktifkuy di instagram bersama rekan kerjanya untuk merecruitment grup belajar bareng produktifkuy atau yang disingkat dengan BBP. BPP merupakan wadah belajar bagi calon mahasiswa di seluruh Indonesia untuk menggapai kampus impian, 
sekaligus memacu mereka untuk menjalani hari demi hari dengan produktif. Selain merecruitmen calon mahasiswa, program yang didirikan Esther merecruitmen tutor atau rekan kerjanya untuk menjalankan programnya. Akun program produktifkuy juga memberikan informasi yang dapat memberikan pengetahuan untuk pengikutnya seperti memberikan informasi webinar pembuatan CV dan sebagainya.

Dengan adanya teknologi media sosial tidak serta membuat para generasi millenial menjadi malas belajar dan tidak produktif, masih ada generasi millenial yang memanfaatkan media sosial seperti instagram dan tiktok untuk memberikan informasi baik pengetahuan ataupun sharing pengalaman. Sikap kepemimpinan wirausahawan yang positiflah yang dapat mengubah pandangan kaum orangtua bahwa generasi millenial dapat produktif dan kreatif. Sehingga, kedua generasi millenial ini sikap kepemimpinan yang positif sangat perlu menjadi pedoman bagi kaum generasi millenial yang lainnya.

\section{SIMPULAN}

Menjadi pemimpin dalam suatu usaha atau sering disebut wirausahawan, wajib mempunyai sikap kepemimpinan yang positif baik bagi dirinya, rekan kerjanya, karyawannya serta berguna bagi masyarakat yang lain. Generasi millenial sangat wajib menanamkan sikap kepemimpinan yang positif untuk membangun usahanya agar berkembang lebih baik dan sukses. Generasi millenial harus menunjukkan jati diri yang positif kepada masyarakat luas dengan berpedoman pada Pancasila serta normanorma yang berlaku di masyarakat. Hal ini untuk memutuskan anggapan orangtua sendiri maupun masyarakat yang lain bahwa generasi muda tidak bisa maju karena mulai kurangnya sopan santun, kurangnya kreativitas serta pemalas.

\section{DAFTAR PUSTAKA}

Ainur, S. M. I. D. W. R. (2017). the Influences of Leadership Styles, Organizational Communication, and Job Satisfaction Toward Employees' Job Performance in Doing Construction Jobs: a Study on Three Construction Companies in Jakarta. Rjoas, 5(May), 168- 180. https://doi.org/10.18551/rjoas.2017-05.23

Ali Chaerudin. (2012). ANALISIS STRATEGI WIRAUSAWANMUDA BIDANG MULTIMEDIA DI CIPUTAT, TANGERANG SELATAN. STIE Ahmad Dahlan Jakarta. Jurnal Liquidity: Vol. 1, No. 1, Januari-Juni 2012: 1-12

Andreas Sarjono, Maria Josephine. (2019). WIRAUSAHAWAN RUMAH MAKAN PEMPEK DI KOTA PALEMBANG TERHADAP KEBERHASILAN USAHA. Jurnal Keuangan dan Bisnis. DOI : 10.32524/jkb.v17i1.492

Anggoro, W. J., \& Virdanianty, M. (2011). Studi Eksplorasi Konstrak Kepemimpinan Model Jawa : Asta Brata. 38(2), 228-239.

Dyah Suryaningtyas. (2004). MEMBENTUK KARAKTER WIRAUSAHAWAN YANG KREATIF DAN TANGGUH. Staf Pengajar Fakultas Ekonomi Universitas Slamet Riyadi Surakarta. Jurnal Ekonomi dan Kewirausahaan Vol. 4, No. 1, April 2004 : $96-103$

Igbaekemen, G. O. (2014). Impact of Leadership Style on Organisation Performance : A Srategic Literature Review. Public Policy and Administration Research, 4(9), 126-136. https://doi.org/10.1080/00223980.1948.9917362

Joel Tuwey, Vincent Ngeno. (2019). Board Leadership, Chief Executive Officer Optimism and Firm Innovation. Moi University, Kenya. SEISENSE Journal of Management Vol 2 No 6 (2019): DOI: https://doi.org/10.33215/sjom.v2i6.221 , 116

Kementerian Pemberdayaan Perempuan dan Perlindungan Anak, \& Badan Pusat Statistik. (2018). Statistik Gender Tematik: Profil Generasi Milenial Indonesia. Kementerian Pemberdayaan Perempuan Dan Perlindungan Anak. 
Lye Sok Ha. Usahawan dan Aktivitas Keusahawanan Cina di Malaysia. Latihan IImiah. Fakulti Ekonomi Universiti Kebangsaan Malaysia. 1991

Made Sudana, Ni Putu Nina Aristina. (2017). CHIEF EXECUTIVE OFFICER (CEO) POWER, CEO KELUARGA, DAN NILAI IPO PREMIUMPERUSAHAAN KELUARGA DI Indonesia. Departemen Manajemen Fakultas Ekonomi dan Bisnis, Universitas Airlangga. Jurnal Akuntansi, Volume XXI, No. 02, Mei 2017: 219-231

Sariyatun. (2017) Anggoro, W. J., \& Virdanianty, M. (2011). Studi Eksplorasi Konstrak Kepemimpinan Model Jawa: Asta Brata. 38(2), 228-239.

Sri Laila Afrika Dewi, Ratu Mutialela Caropeboka. (2020). PERILAKU GENERASI X DAN GENERASI MILLENIAL DALAM PENGGUNAAN MEDIA SOSIAL. Universitas Bina Darma. Anggoro, W. J., \& Virdanianty, M. (2011). Studi Eksplorasi Konstrak Kepemimpinan Model Jawa: Asta Brata. 38(2), 228-239.

Udik Budi Wibowo. (2011). Teori Kepemimpinan. BKD Kota Yogyakarta. Universitas Negeri Yogyakarta 